\title{
Transhydroxylase of Pelobacter acidigallici: a molybdoenzyme catalyzing the conversion of pyrogallol to phloroglucinol
}

\author{
Wolfram Reichenbecher ${ }^{\mathrm{a}, *}$, Andreas Brune ${ }^{\mathrm{b}}$, Bernhard Schink ${ }^{\mathrm{a}}$ \\ ${ }^{a}$ Fakultät für Biologie, Universität Konstanz, Postfach 5561, D-78434 Konstanz, FRG \\ ${ }^{b}$ Department of Microbiology and Public Health, Michigan State University, East Lansing, MI 48824-1101, USA
}

(Received 7 July 1993)

\begin{abstract}
Trihydroxybenzenes are degraded anaerobically through the phloroglucinol pathway. In Pelobacter acidigallici as well as in Pelobacter massiliensis, pyrogallol is converted to phloroglucinol in the presence of 1,2,3,5-tetrahydroxybenzene by intermolecular hydroxyl transfer. The enzyme catalyzing this reaction was purified to chromatographic and electrophoretic homogeneity. Gel filtration and electrophoresis revealed a heterodimer structure with an apparent molecular mass of $127 \mathrm{kDa}$ for the native enzyme and $86 \mathrm{kDa}$ and $38 \mathrm{kDa}$, respectively, for the subunits. The enzyme was not sensitive to oxygen. $\mathrm{HgCl}_{2}, p$-chloromercuribenzoic acid, and $\mathrm{CuCl}_{2}$ inhibited strongly the reaction indicating an essential function of SH-groups. Transhydroxylase had a $\mathrm{pH}$-optimum of 7.0 and a $\mathrm{p} I$ of 4.1 . The apparent temperature optimum was in the range of $53^{\circ} \mathrm{C}$ to $58^{\circ} \mathrm{C}$. The activation energy for the conversion of pyrogallol and 1,2,3,5-tetrahydroxybenzene to phloroglucinol and tetrahydroxybenzene was $31.4 \mathrm{~kJ}$ per mol. Purified enzyme exhibited a specific activity of $3.1 \mathrm{~mol} \mathrm{~min}-1 \mathrm{mg}^{-1}$ protein and an apparent $K_{\mathrm{m}}$ for pyrogallol and 1,2,3,5-tetrahydroxybenzene of $0.70 \mathrm{mM}$ and $0.71 \mathrm{mM}$, respectively. The enzyme was found to contain per mol heterodimer 1.1 mol molybdenum, $12.1 \mathrm{~mol}$ iron and $14.5 \mathrm{~mol}$ acid-labile sulfur. Requirement for molybdenum for transhydroxylating enzyme activity was proven also by cultivation experiments. No hints for the presence of flavins were obtained. The results presented here support the hypothesis that a redox reaction is involved in this intermolecular hydroxyl transfer.
\end{abstract}

Key words: Anaerobic degradation; Molybdoenzyme; Phloroglucinol pathway; Transhydroxylase; Trihydroxybenzene; $(P$. acidigallici)

\section{Introduction}

Aerobic degradation of aromatic compounds involves oxygenase reactions in the primary attack on the mesomeric ring structure. In the absence of oxygen, the stability of the aromatic nucleus is overcome by a reductive attack [1]. Depending on the substitution pattern, three different intermediates have been identified which allow direct reduction and cleavage of the aromatic compound. These intermediates define the three pathways of aromatic ring degradation which are known at present $[2,3]$.

In contrast to benzoate, several phenols and aniline derivatives, which are activated to benzoyl-CoA as key intermediates [4], trihydroxybenzenes and derivatives

\footnotetext{
* Corresponding author. Fax: +497531882966.
}

are degraded through the non-activated key intermediate phloroglucinol. Due to its alternating arrangement of hydroxyl groups, phloroglucinol is reduced easily to dihydrophloroglucinol which is no longer aromatic. Subsequent cleavage leads to an aliphatic acid. In Pelobacter species, the acid is metabolized to acetate as sole organic fermentation product [5,6]. In $E$. oxidoreducens, acetate and butyrate are formed [7].

Other trihydroxylated compounds such as gallic acid are decarboxylated to pyrogallol $[8,9]$ and subsequently transformed to phloroglucinol in a unique reaction.

For E. oxidoreducens, a reaction mechanism was proposed which consisted of a consecutive dehydroxylation and hydroxylation. The enzyme involved, pyrogallol-phloroglucinol isomerase, was partially purified and characterized [10]. For the enzyme of $P$. acidigallici, a different reaction model was proposed which involves tetrahydroxybenzene as cosubstrate [11]. Pyrogallol and 1,2,3,5-tetrahydroxybenzene react as hy- 
$\overbrace{\mathrm{OH}_{\mathrm{OH}}}^{\mathrm{OH}}$
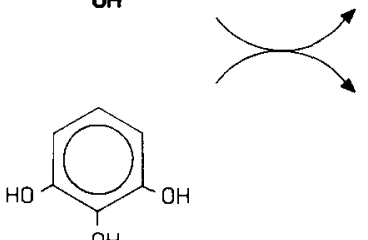

$\mathrm{OH}$
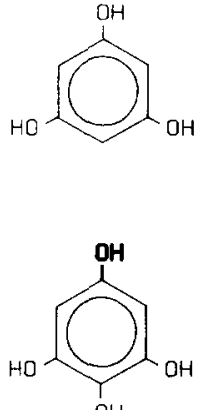

$\mathrm{OH}$
Fig. 1. Reaction of transhydroxylase in $P$. acidigallici. Pyrogallol is transhydroxylated to phloroglucinol. 1,2,3,5-tetrahydroxybenzene serves as cosubstrate and coproduct [5].

droxyl acceptor and donor, respectively, yielding phloroglucinol and the product 1,2,3,5-tetrahydroxybenzene (Fig. 1). This reaction is a hydroxyl transfer between two aromatic compounds, a transhydroxylation. Later it was found that transhydroxylation reactions are involved also in the transformation of the third trihydroxybenzene isomer, hydroxyhydroquinone, to phloroglucinol by $P$. massiliensis [5].

To our knowledge, this transhydroxylation is an entirely new type of reaction. No enzyme catalyzing an intermolecular hydroxyl transfer has been described so far. In the present communication we report on purification and characterization of the transhydroxylase of $P$. acidigallici. The results are discussed also with regard to a proposed reaction mechanism.

\section{Material and methods}

\section{Culture conditions}

Pelobacter acidigallici strain Ma Gal 2 (DSM 2377) was grown anaerobically in a sulphide-reduced and bicarbonate-buffered saltwater mineral medium, as described previously [11]. Cultures were incubated at $30^{\circ} \mathrm{C}$ in the dark. For growth experiments, the bacterium was grown in $50 \mathrm{ml}$ screw-cap bottles with sodium gallate, pyrogallol, or phloroglucinol as substrate ( $5 \mathrm{mM}$ each). For enzyme preparation, P. acidigallici was grown in 201 glass vessels with $5 \mathrm{mM}$ gallate. After $10 \mathrm{~h}$ of incubation, cultures were refed with another $5 \mathrm{mM}$ gallate. Cultures were harvested at the end of the exponential growth phase $\left(A_{578}=0.45\right)$. Cells were concentrated with a Pellicon filter cassette system (Millipore, Eschborn, FRG), washed with 21 of

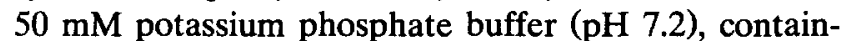
ing $200 \mathrm{mM} \mathrm{NaCl}$, and centrifuged at $28000 \times g$ for 30 $\min$. The cell pellet was kept at $-70^{\circ} \mathrm{C}$ until use.

\section{Preparation of cell extracts}

Cell extracts were prepared at $4-8^{\circ} \mathrm{C}$. The cell pellet was suspended in $50 \mathrm{mM}$ potassium phosphate buffer
(pH 7.2), at a concentration of $200 \mathrm{mg}$ wet cell mass and $50 \mu \mathrm{g}$ DNase per $\mathrm{ml}$ and approx. $1 \mathrm{mM} \mathrm{MgCl}_{2}$. Disruption was performed by 2-3 passages through a French Press (Aminco Instruments, Silver Springs, MD, USA) at $110 \mathrm{MPa}$. The suspension obtained was diluted to approx. $10 \mathrm{mg}$ protein/ $\mathrm{ml}$ with potassium phosphate buffer and centrifuged at $30000 \times g$ for 30 min. The crude extract was kept on ice or frozen at $-70^{\circ} \mathrm{C}$ until use.

\section{Enzyme assays}

The enzyme activity was assayed at $25^{\circ} \mathrm{C}$ under anoxic conditions. Two test sytems were used:

(i) The discontinuous test system for quantitative determination of enzymatic activities was described previously [11]. The test was performed in $5 \mathrm{ml}$ glass flasks. Each contained $1 \mathrm{mM}$ pyrogallol, $1 \mathrm{mM}$ 1,2,3,5-tetrahydroxybenzene, $50 \mathrm{mM}$ potassium phosphate buffer ( $\mathrm{pH} 7.0$ ), and cell protein solution in a total volume of $1 \mathrm{ml}$. Aliquots were taken after certain time intervals, added to $0.1 \mathrm{mM} \mathrm{H}_{3} \mathrm{PO}_{4}$ and analyzed quantitatively for pyrogallol and phloroglucinol by HPLC. The $\mathrm{pH}$ optimum of the enzyme was determined in a $\mathrm{pH}$ range of 4 to 9 . A mixed test buffer, containing potassium phosphate, acetate- and Tris buffer, each $50 \mathrm{mM}$, was used. The $\mathrm{pH}$ was adjusted with $10 \mathrm{M} \mathrm{HCl}$ or $10 \mathrm{M}$ $\mathrm{NaOH}$. The effect of potential inhibitors or other additives to enzyme activity was examined after preincubation of the enzyme with the various compounds for $5 \mathrm{~min}$ before starting the test.

(ii) For routine analysis of transhydroxylase activity in, e.g., column fractions, a continuous test system was used. This test was faster than the discontinuous assay, but produced only semiquantitative results. The assay was performed in $1 \mathrm{ml}$ cuvettes containing $50 \mathrm{mM}$ potassium phosphate buffer $(\mathrm{pH} \mathrm{7.0),4}$ $\mathrm{mM}$ hydroxyhydroquinone, and cell protein solution. Increase in $A_{313}$ was measured with a Hitachi spectrophotometer, model 100-40 (Tokyo, Japan).

\section{Enzyme purification}

Anion exchanger. The crude extract was passed through a $60 \mathrm{ml}$ anion exchanger column (DE-52, Whatman, England, column $2.6 \times 11 \mathrm{~cm}$ ) previously equilibrated with $50 \mathrm{mM}$ potassium phosphate buffer (pH 7.2), at $8^{\circ} \mathrm{C}$. After loading, the column was eluted with one bed volume of buffer, one bed volume of buffer with $60 \mathrm{mM} \mathrm{KCl}$, one bed volume of buffer with $170 \mathrm{mM} \mathrm{KCl}$, and three bed volumes of buffer with 500 $\mathrm{mM} \mathrm{KCl}$, at a flow rate of $1.5 \mathrm{ml} \mathrm{min}{ }^{-1}$. Transhydroxylase activity eluted at $170 \mathrm{mM} \mathrm{KCl}$ as a single peak. Fractions containing activity were combined and concentrated by ultrafiltration (Centriprep 10, Amicon, Witten, FRG). The concentrate was dialyzed at $4^{\circ} \mathrm{C}$ for $2 \mathrm{~h}$ against $25 \mathrm{mM}$ Histidine- $\mathrm{HCl}$ buffer ( $\mathrm{pH} \mathrm{6.1)}$, 
containing $35 \mathrm{mM} \mathrm{NaCl}$, and adjusted to a final concentration of approx. $2 \mathrm{mg}$ protein $\mathrm{ml}^{-1}$.

Chromatofocusing. The column for chromatofocusing $(1.0 \times 25 \mathrm{~cm})$ was filled with Polybuffer Exchanger PBE 94 (Pharmacia, Freiburg, FRG) and equilibrated with $25 \mathrm{mM}$ Histidine- $\mathrm{HCl}$ buffer $(\mathrm{pH} \mathrm{6.1)}$, containing $35 \mathrm{mM} \mathrm{NaCl}$. After loading, the column was eluted with ten bed volumes of Polybuffer PB 74, 7-times diluted $(\mathrm{pH} 3.8)$, which contained $35 \mathrm{mM} \mathrm{NaCl}$. Chromatofocusing was performed at $25^{\circ} \mathrm{C}$ at a flow rate of $0.5 \mathrm{ml} \mathrm{min}^{-1}$. Enzyme activity eluted as a single peak at $\mathrm{pH} 4.0$ to 4.2 . Fractions were combined, concentrated by ultrafiltration, and dialyzed against 50 $\mathrm{mM}$ Tris- $\mathrm{HCl}$ (pH 7.2), containing $200 \mathrm{mM} \mathrm{NaCl}$.

Gel filtration. The sample was applied to a Superdex 200 pg column (16/60) (Pharmacia, Freiburg, FRG) equilibrated and eluted with $50 \mathrm{mM}$ Tris- $\mathrm{HCl}(\mathrm{pH} 7.2)$, containing $200 \mathrm{mM} \mathrm{NaCl}$, at a flow rate of $0.7 \mathrm{ml}$ $\min ^{-1}$. The concentrated enzyme solution was stored in liquid nitrogen.

\section{Protein determination}

Protein was determined according to Bradford [12] using $0.01 \%(\mathrm{w} / \mathrm{v})$ Coomassie brilliant blue G-250 (Serva, Heidelberg, FRG) as reagent and bovine serum albumin as standard.

\section{Electrophoretic methods}

SDS-PAGE was performed according to Laemmli [13]. Non-denaturing gel electrophoresis was performed omitting SDS and mercaptoethanol from all solutions and preparing samples without heating. Single percentage gels were produced in our laboratory, gradient gels were purchased from Bio-Rad (Richmond, VA, USA). Gels were stained with silver nitrate [14]. Molar masses of bands were determined by comparison with standard proteins (LMW-kit, Pharmacia, Freiburg, FRG).

\section{Analytical methods}

Isoelectric point $(p I)$. The $\mathrm{p} I$ of the enzyme was determined by chromatofocusing as described in Section 2.4 with the exception that buffers contained no salt. The sample volume was kept small ( $\leq 5 \%$ of bed volume).

The molecular mass of the transhydroxylase was determined by gel filtration using a Superdex $200 \mathrm{pg}$ column $(16 / 60)$. The column was equilibrated and eluted with $50 \mathrm{mM}$ Tris- $\mathrm{HCl}$ (pH 7.2), containing 200 $\mathrm{mM} \mathrm{NaCl}$, at a flow rate of $0.7 \mathrm{ml} \mathrm{min}{ }^{-1}$. A set of standard proteins was used for calibration. The molecular mass was determined in the presence and absence of $1 \%$ sodium dodecyl sulphate.

The absorbance spectrum of the purified enzyme as well as of a trichloroacetic acid extract was measured with a double beam spectrophotometer, model Uvikon 860 (Kontron, Zürich, Switzerland).

Flavins. Noncovalently bound flavins were determined by extraction with trichloroacetic acid and measurement of the absorbance spectrum, or by heating and measurement of fluorescence. For extraction, a sample of purified enzyme was mixed with an equal volume of $20 \%(\mathrm{w} / \mathrm{v})$ trichloroacetic acid at $0^{\circ} \mathrm{C}$, and centrifuged. The neutralized supernatant was analyzed spectrophotometrically. Alternatively, the sample was heated for $10 \mathrm{~min}$ in boiling water and centrifuged. The supernatant was analyzed fluorimetrically $(450 \mathrm{~nm}$ excitation wavelength) with a Perkin-Elmer Luminescence spectrometer, model LS 50 (Überlingen, FRG). Covalently bound flavins were determined by fluorimetry after proteolytic digestion according to Singer et al. [15].

Transition metals. Purified transhydroxylase was analyzed for transition metals either by inductively coupled plasma mass spectrometry with indium as internal standard on a VG Plasmaquad II (VG Elemental, Winsford, UK) or for iron and molybdenum by atomic absorption spectrometry. The latter was performed with a 3030-B Perkin-Elmer atomic absorption spectrometer fitted with a HGA-600 graphite furnace assembly and an AS-60 autosampler (Überlingen, FRG). The metal content in the sample was calculated from a calibration curve (external standards) according to peak height and peak area. Subsamples of $5 \mu \mathrm{l}$ volume were injected, dried for $15 \mathrm{~s}$ at $110^{\circ} \mathrm{C}$, charred for $10 \mathrm{~s}$ at $1100^{\circ} \mathrm{C}$, and atomized for $2 \mathrm{~s}$ at $2000^{\circ} \mathrm{C}$. Absorbance was measured at $248.3 \mathrm{~nm}$. For determination of molybdenum, $50 \mu \mathrm{l}$ sample were injected, dried for 40 $s$ at $100^{\circ} \mathrm{C}$, charred for $20 \mathrm{~s}$ at $1600^{\circ} \mathrm{C}$, and atomized for $3 \mathrm{~s}$ at $2650^{\circ} \mathrm{C}$. Absorbance was measured at 313.3 $\mathrm{nm}$.

\section{Determination of acid-labile sulfur}

Acid-labile sulphur was analyzed according to Beinert [16]. Differing from [16], the reaction proceeded under nitrogen gas in glass vials with rubber septa until Methylene blue was formed.

\section{Results}

\section{Purification and stability of the enzyme}

Column fractions were tested for enzyme activity using the continuous assay. This assay was based on the enzymatic conversion of hydroxyhydroquinone to resorcinol and 1,2,4,5-tetrahydroxybenzene, according to the equation:

$2 \mathrm{C}_{6} \mathrm{H}_{6} \mathrm{O}_{3} \rightleftharpoons \mathrm{C}_{6} \mathrm{H}_{6} \mathrm{O}_{2}+\mathrm{C}_{6} \mathrm{H}_{6} \mathrm{O}_{4}$. 


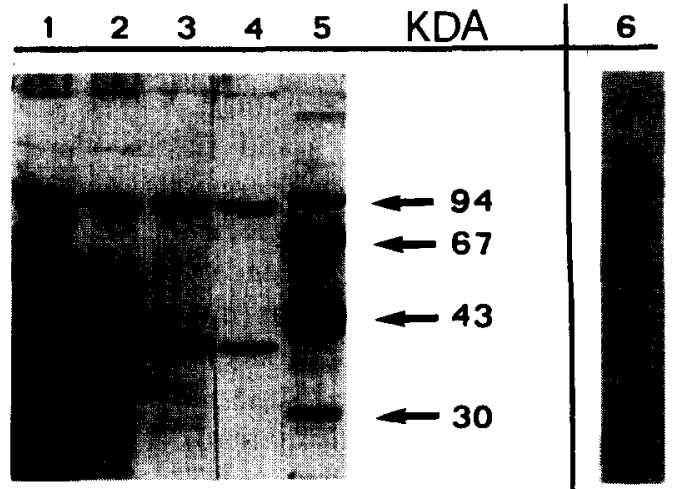

Fig. 2. Purification steps of transhydroxylase as analyzed by gel electrophoresis. The gels were stained with silver nitrate. Lane 1-5: Protein from various stages of the purification was separated on a 10\% SDS-PAGE gel. Lane 6: Purified protein was loaded on a non-denaturing $10 \%$ gel. Lane 1 , crude extract $(8 \mu \mathrm{g})$; lane 2 , DE-52 $(6 \mu \mathrm{g})$; lane 3, PBE-94 (3 $\mu \mathrm{g})$; lane 4, Superdex $200 \mathrm{pg}(1.5 \mu \mathrm{g})$; lane 5 , molecular mass standards: rabbit muscle phosphorylase $b(94.0$ $\mathrm{kDa})$, bovine serum albumin $(67.0 \mathrm{kDa})$, egg white ovalbumin $(43.0$ $\mathrm{kDa})$, bovine erythrocyte carbonic anhydrase $(30.0 \mathrm{kDa})$. Lane 6 , Superdex $200 \mathrm{pg}(1 \mu \mathrm{g})$.

The reaction was described previously [11]. $\Delta \epsilon$ defined as

$$
\begin{aligned}
\Delta \epsilon= & \left(\epsilon_{1,2,4,5 \text {-tetrahydroxybenzene }}+\epsilon_{\text {resorcinol }}\right) \\
& -2 \epsilon_{\text {hydroxyhydroquinone }}
\end{aligned}
$$

was in the range of 2 to $10 \mathrm{mM}^{-1} \mathrm{~cm}^{-1}$ at $313 \mathrm{~nm}$ wavelength. Determination of an exact $\Delta \epsilon$ was difficult due to the low stability of hydroxyhydroquinone and its oxygen sensitivity at neutral $\mathrm{pH}$. A linear relation between activity and protein content could not be established. Therefore the test was used only for routine enzyme detection in column fractions.

After three chromatographic steps, transhydroxylase of $P$. acidigallici was purified 8-fold with a recovery of $20 \%$ (Table 1) and eluted from the last column as a single, symmetrical peak. The protein was homogenous according to chromatographic (gel filtration) and electrophoretic (SDS-PAGE) analysis (Fig. 2). The enzyme was insensitive to oxygen: no decrease of activity was observed after incubation under air at $0^{\circ} \mathrm{C}$ for 7 days (see Fig. 6). Stability of the purified enzyme against freezing and thawing depended on the buffer system:

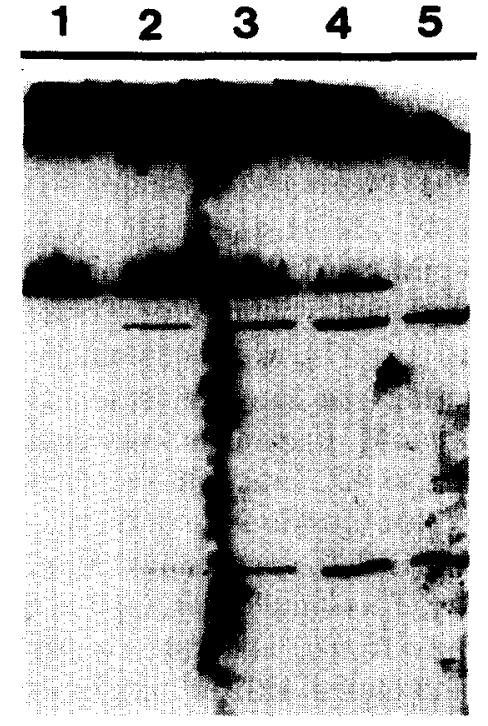

Fig. 3. Separation of purified transhydroxylase by SDS-PAGE after various pretreatments. SDS-PAGE gel was $10 \%$ and stained with silver nitrate. Pretreatment of the samples: lane 1 , without heating; lane 2, heating for $15 \mathrm{~min}$ at $60^{\circ} \mathrm{C}$; lane 3 , heating for $30 \mathrm{~min}$ at $60^{\circ} \mathrm{C}$; lane 4 , heating for 2 hours at $60^{\circ} \mathrm{C}$; lane 5 , heating for $4 \mathrm{~min}$ at $95^{\circ} \mathrm{C}$.

Only 5 to $10 \%$ of the activity was lost if the enzyme was dissolved in $50 \mathrm{mM}$ Tris- $\mathrm{HCl}(\mathrm{pH} \mathrm{7.2)}$ ), and frozen two times, whereas activity was nearly entirely lost if treated in the same way in $50 \mathrm{mM}$ potassium phosphate buffer.

\section{Structural composition}

Non-denaturing gel electrophoresis of transhydroxylase showed a single protein band (Fig. 2, lane 6). SDS-PAGE of transhydroxylase revealed one or two bands depending on pre-treatment of the sample (Fig. 3 ). Without heating, only one single band was observed (Fig. 3, lane 1). During heating, the single band disintegrated into two polypeptides forming smaller bands (Fig. 3, lane 2-5). For these polypeptides, a molecular mass of $86 \pm 5 \mathrm{kDa}$ and $38 \pm 2 \mathrm{kDa}$ was calculated from SDS-PAGE. The molecular mass of the intact protein was determined by gel filtration. In the presence of $1 \%$ SDS, an apparent molecular mass of 127 $\mathrm{kDa}$ was obtained (Fig. 4). Under these conditions, the entire enzyme activity was maintained. From these results we conclude that the transhydroxylase is a heterodimer consisting of a large and a small subunit.

Table 1

\begin{tabular}{|c|c|c|c|c|c|}
\hline Step & $\begin{array}{l}\text { Activity }{ }^{a} \\
\text { (U) }\end{array}$ & $\begin{array}{l}\text { Protein } \\
\text { (mg) }\end{array}$ & $\begin{array}{l}\text { Specific activity } \\
{[\mathrm{U} / \mathrm{mg}]}\end{array}$ & $\begin{array}{l}\text { Yield } \\
(\%)\end{array}$ & Purification factor \\
\hline Crude extract & 31 & 80.4 & 0.39 & 100 & 1 \\
\hline Anion exchange (DE-52) & 21.4 & 28.2 & 0.76 & 69 & 1.9 \\
\hline Chromatofocusing (PBE-94) & 10.8 & 5.0 & 2.16 & 35 & 5.5 \\
\hline Gel filtration (superdex $200 \mathrm{pg}$ ) & 6.2 & 2.0 & 3.1 & 20 & 7.9 \\
\hline
\end{tabular}

Purification of transhydroxylase of $P$. acidigallici

a $1 \mathrm{U}$ enzyme activity catalyzes the conversion of pyrogallol and 1,2,3,5-tetrahydroxybenzene into $1 \mu$ mol phloroglucinol per min. 


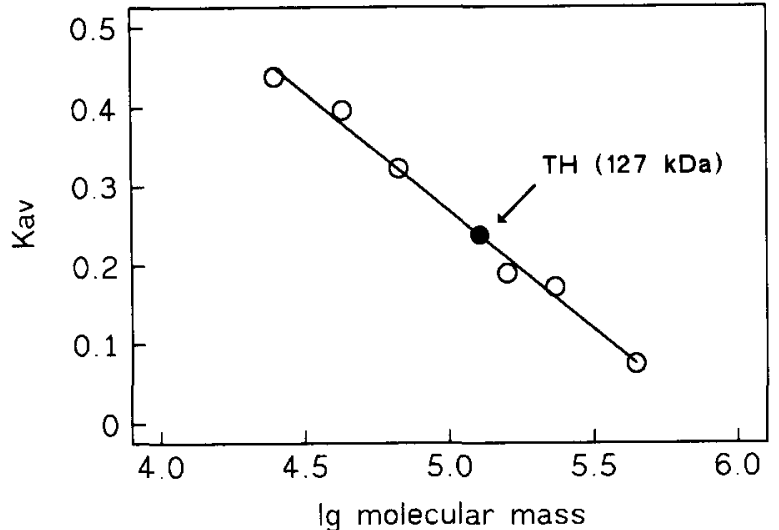

Fig. 4. Determination of molecular mass of transhydroxylase by gel filtration with a Superdex $200 \mathrm{pg}$ column in the presence of $1 \%$ SDS. Molecular mass is plotted logarithmically against $K_{\mathrm{av}} . K_{\mathrm{av}}=\left(v_{\mathrm{e}}-\right.$ $\left.v_{\mathrm{o}}\right) /\left(v_{\mathrm{t}}-v_{\mathrm{o}}\right)$ with $v_{\mathrm{e}}$ : elution volume, $v_{\mathrm{o}}$ : void volume, $v_{\mathrm{t}}$ : total gel bed volume. $(O)$ bovine pancreas chymotrypsinogen $A(25.0 \mathrm{kDa})$, hen egg ovalbumin $(43.0 \mathrm{kDa})$, bovine serum albumin $(67.0 \mathrm{kDa})$, rabbit muscle aldolase $(158.0 \mathrm{kDa})$, bovine liver catalase $(232.0 \mathrm{kDa})$ and horse spleen ferritin $(440.0 \mathrm{kDa})$. (๑) transhydroxylase $(127$ $\mathrm{kDa}$ ).

The values for the two polypeptides were independent of the kind of acrylamide gel used for determination. Gradient gels, as well as single percentage gels of various composition $(8 \%, 10 \%$ and $12 \%)$, yielded the same results which were always reproducible. No differences were observed if SDS-PAGE was performed in the presence or absence of mercaptoethanol indicating that disulfide crosslinks were not essential in the maintenance of a functional protein. Molecular mass determination of the native enzyme by gel filtration in the absence of SDS produced values ranging from 270 $\mathrm{kDa}$ to $410 \mathrm{kDa}$. These values were independent of the degree of purity of the enzyme used. Contrary, in the presence of SDS always a molecular mass of $127 \mathrm{kDa}$ was determined which is the minimum value calculated from the size of the two subunits. We conclude that transhydroxylase is a $127 \mathrm{kDa}$ protein which tends to aggregate to multimeric forms.

\section{Catalytic properties and inhibitors}

The $\mathrm{p} I$ of transhydroxylase was $4.10 \pm 0.05$ as determined by chromatofocusing. The enzyme made up a large fraction of 5 to $10 \%$ of total protein in the crude extract (Fig. 2, compare lanes 1 and 4). Therefore, 8-fold enrichment led to a pure transhydroxylase enzyme preparation (Table 1). Crude extracts converted pyrogallol to phloroglucinol no matter on which substrate cells were grown.

Pure enzyme was stabile over 7 days if it was incubated under atmospheric air. If kept under nitrogen gas, the activity decreased by $30 \%$ within one day (Fig. 6).

The measurable activity depended on the concentration of the buffer used in the test system. Similar activities were measured in $25 \mathrm{mM}$ or $50 \mathrm{mM}$ potassium phosphate buffer, whereas $75 \mathrm{mM}$ buffer increased the activity by $10 \%, 100 \mathrm{mM}$ buffer by $35 \%$. No enhancement occurred at higher buffer concentrations. Basically similar results were obtained using Mops (3-( $N$-morpholino)propanesulfonic acid) buffer instead of potassium phosphate buffer.

The $\mathrm{pH}$ optimum of enzymatic activity was $\mathrm{pH} 7.00$ \pm 0.05 . $90 \%$ of the maximum activity was obtained at $\mathrm{pH} 6.6$ or 7.4 , respectively. In tests at $\mathrm{pH} 6.0$ or $\mathrm{pH} 8.5$ the enzyme activity was reduced by $50 \%$.

The temperature dependence of enzyme activity was determined in the range of 25 to $80^{\circ} \mathrm{C}$. Maximum activity was found between $53^{\circ} \mathrm{C}$ and $58^{\circ} \mathrm{C}$. The activation energy calculated from the Arrhenius plot was $31.4 \mathrm{~kJ} \mathrm{~mol}^{-1}$.

Determination of apparent $K_{\mathrm{m}}$ values was carried out with enzyme obtained after the first purification step. $K_{\mathrm{m}}$ of pyrogallol was determined at a constant concentration of 1,2,3,5-tetrahydroxybenzene of $1 \mathrm{mM}$ using pyrogallol concentrations between $0.1 \mathrm{mM}$ and 1 $\mathrm{mM}$ and vice versa for the $K_{\mathrm{m}}$ of 1,2,3,5-tetrahydroxybenzene. Values were calculated from a LineweaverBurk plot drawing a straight line over of 8 points. $K_{\mathrm{m}}$ was $0.70 \mathrm{mM}$ for pyrogallol, and $0.71 \mathrm{mM}$ for $1,2,3,5-$ tetrahydroxybenzene.

Transhydroxylase was sensitive to thiol reagents. Total inhibition was achieved by $50 \mu \mathrm{M} p$-chloromercuribenzoic acid, $50 \mu \mathrm{M} \mathrm{HgCl}_{2}$, or $1 \mathrm{mM} \mathrm{CuCl}_{2}$. In contrast, $5 \mathrm{mM} \mathrm{KCN}$ or $5 \mathrm{mM}$ sodium iodoacetate produced only $15 \%$ inhibition, and $5 \mathrm{mM} \mathrm{NiCl}_{2}$ had no effect. The reductants 1,4-dithiothreitol, 1,4-dithioerythritol, thioglycolate, and mercaptoethanol at concentrations up to $2.5 \mathrm{mM}$ had no influence on enzyme activity. Also EDTA and $\mathrm{MgCl}_{2}$, each at $10 \mathrm{mM}$, had no inhibitory effect. $\mathrm{CaCl}_{2}$ at $5 \mathrm{mM}$ concentration reduced the enzyme activity by $6 \%$, at $10 \mathrm{mM}$ concentration by $13 \%$.

\section{Cofactors, metal content}

The purified enzyme had a yellow-brownish colour. Its absorbance spectrum did not show any distinct maxima between 350 and $550 \mathrm{~nm}$ (Fig. 5). Trichloroacetic acid extracts exhibited no absorption in this range either, indicating that no flavins were present. Absence of flavins was confirmed also by fluorimetry.

The colour of the enzyme and its absorbance spectrum suggested that iron-sulfur clusters were present. According to atomic absorption spectrometry analysis, the iron content was $12.1 \pm 0.5 \mathrm{~mol}$ iron per mol enzyme. Acid-labile sulfur was present at a ratio of 14.5 $\pm 0.1 \mathrm{~mol}$ per mol enzyme. These values are means of separate analyses of two enzyme preparations for acidlabile sulphur and of three preparations for iron.

Apart from iron, only molybdenum was found at higher quantities. A value of $1.1 \pm 0.2 \mathrm{~mol}$ per mol 


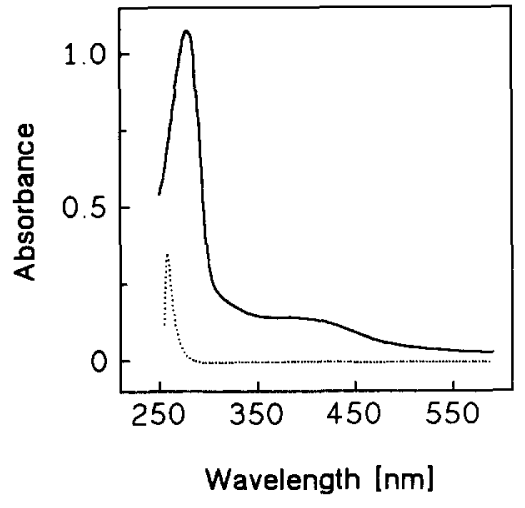

Fig. 5. Absorbance spectra of the purified transhydroxylase in $50 \mathrm{mM}$ sodium phosphate buffer ( $\mathrm{pH}$ 7.2) (solid line) and after extraction with trichloroacetic acid (TCA, dotted line). For TCA-extraction, 1 $\mathrm{ml}$ sample containing $1 \mathrm{mg}$ protein was mixed with an equal volume of $20 \% \mathrm{TCA}$ at $0^{\circ} \mathrm{C}$ and centrifuged. The supernatant was taken for absorbance measurement.

enzyme was determined as a mean of three enzyme preparations. Cultivation experiments demonstrated that this metal was required for transhydroxylation. Growth of $P$. acidigallici with pyrogallol without molybdate added to the medium decreased and ceased entirely after cells had been subcultured three times. Transfer of the second sub-culture into phloroglucinol medium or into pyrogallol medium with molybdate resulted in entire recovery and normal growth of both cultures.

The following metals were not found in pure transhydroxylase enzyme preparations by inductively coupled plasma mass spectrometry analysis: nickel, lead, vanadium (each $<0.01 \mathrm{~mol}$ metal per mol enzyme), and copper ( $\leqslant 0.03 \mathrm{~mol}$ per mol). Zinc is unlikely to be present in the enzyme $(\leqslant 0.1 \mathrm{~mol}$ per mol).

Transhydroxylase activity did not depend on selenium or tungsten additions to cultures growing on gallate. A culture to which neither tungsten nor sele-

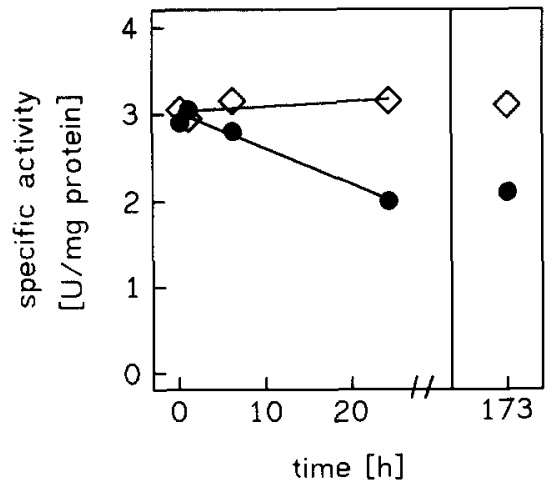

Fig. 6. Stability of purified transhydroxylase under oxic and anoxic conditions. $(\diamond)$ incubation at $0^{\circ} \mathrm{C}$ under atmospheric air; $(\bullet)$ incubation at $0^{\circ} \mathrm{C}$ under nitrogen gas. Each symbol represents a mean of two independent determinations. nium had been added produced normal growth even after six transfers.

\section{Discussion}

A transhydroxylase catalyzing intermolecular transhydroxylation of pyrogallol with 1,2,3,5-tetrahydroxybenzene to phloroglucinol and 1,2,3,5-tetrahydroxybenzene is characterized in pure state in this paper for the first time.

The purified enzyme of $P$. acidigallici was sensitive to some effectors known to react with thiol groups. $\mathrm{HgCl}_{2}, p$-chloromercuribenzoic acid, and $\mathrm{CuCl}_{2}$ were effective inhibitors, whereas $\mathrm{KCN}$, sodium iodoacetate and $\mathrm{NiCl}_{2}$ had no pronounced effect on enzyme activity. Since proteins containing SH-groups are not equally sensitive to all thiol reagents [17], we conclude that the enzyme contains one or more sulfhydryl groups involved either directly or indirectly in transhydroxylation.

Reductants such as 1,4-dithiothreitol, 1,4-dithioerythritol, thioglycolate and mercaptoethanol, did not influence activity. A direct influence of oxygen on enzyme activity could not be assayed because of oxygen sensitivity of the aromatic substrates. However, incubation of pure enzyme under oxic conditions did not influence the activity. Contrary, activity was even decreased if the enzyme was incubated under nitrogen gas. These results may indicate that the transhydroxylation reaction benefits from slightly oxidized incubation conditions.

In the crude extract, a specific activity of about 0.4 $\mathrm{U} \mathrm{mg}{ }^{-1}$ protein was measured, which is half the value published previously [11]. This difference may be partially due to use of buffers of different concentrations in enzyme assays (see above). Pure enzyme exhibited a specific activity of $3.1 \mathrm{U} \mathrm{mg}^{-1}$ protein. With a molecular mass of $127 \mathrm{kDa}$ per active heterodimer, a turnover number of $6.5 \mathrm{~s}^{-1}$ can be calculated. This is within the lowermost rank in comparison with other enzymes which usually have turnover numbers of 1 to $10^{4} \mathrm{~s}^{-1}$ [18]. This unusually low turnover number of the purified enzyme explains why transhydroxylase makes up a considerably high proportion (5-10\%) of total protein in the crude cell extract. Transhydroxylase contains iron and acid-labile sulfur at 12.1 and $14.5 \mathrm{~mol}$ per mol active heterodimer, respectively. Arrangement of both in iron-sulfur cluster has to be expected based on colour and absorbance spectrum of the pure enzyme, and first EPR investigations support this assumption. Also molybdenum was found as a further transition metal in the enzyme at a ratio of $1.1 \pm 0.2 \mathrm{~mol}$ per mol heterodimer. A functional role of this metal in the transhydroxylation reaction was supported by cultivation experiments. 
With regards to its metal content, transhydroxylase can be placed into the group of molybdoenzymes. The number of known enzymes belonging to this group has increased during the recent past $[19,20]$. With the exception of nitrogenase, all molybdoenzymes examined so far contain a pterin cofactor, regardless of their metabolic function and the phylogenetic descendence of their host organisms [21,22] Although experimental evidence is still lacking, the presence of a pterin cofactor in transhydroxylase appears likely. Similar to most other molybdoenzymes [23], transhydroxylase contains iron-sulfur centers but, different from the majority of molybdoenzymes, lacks flavins [23]. Among the molybdoenzymes listed by Garner and Bristow [24], transhydroxylase of $P$. acidigallici shows most resemblance with aldehyde oxidoreductase of Desulfovibrio gigas [25]. This applies to (i) lack of flavins, (ii) an acid $\mathrm{p} I$ of 4.1 [26], (iii) a molecular mass of approx. $120 \mathrm{kDa}$ [26,27], (iiii) a similar Mo/ $\mathrm{Fe} / \mathrm{S}$ ratio of about 1:12:12 [28] although Moura and co-workers published later a different ratio [27]. Interestingly, $P$. acidigallici and $D$. gigas both belong to the delta-subgroup of the proteobacteria [29]. Recent publications on molybdoenzymes and related proteins indicate a link between cofactor composition [30] or protein structure [20] and phylogenetic descendence. This relatedness should be kept in mind in further investigations on these two enzymes.

Transhydroxylase of $P$. acidigallici converts pyrogallol to phloroglucinol by hydroxyl transfer between the aromatic compounds pyrogallol and 1,2,3,5-tetrahydroxybenzene [11]. It has been suggested that this intermolecular hydroxyl transfer involves a diphenyl ether intermediate which is formed after an initial redox reaction (Rétey, J., personal communication). Iron sulphur clusters and a molybdenum cofactor as appear to be present in transhydroxylase are suitable prosthetic groups for catalysis of such a reaction.

Only a few microorganisms are known which ferment trihydroxybenzenes anaerobically. Apart from the two Pelobacter species, E. oxidoreducens has been described [31]. It differs from the former two bacteria in requiring exogenous formate or $\mathrm{H}_{2}$ for substrate degradation [31]. The enzyme converting pyrogallol to phloroglucinol in this bacterium was named pyrogallol-phloroglucinol isomerase, and was partially purified and characterized [10]. In contrast to the $P$. acidigallici enzyme, a reaction mechanism was proposed by which pyrogallol is converted to phloroglucinol through a sequence of hydroxylation and dehydroxylation reactions with 1,2,3,5-tetrahydroxybenzene as intermediate and, e.g., dimethyl sulfoxide as oxidant [10]. Recently, the role of dimethyl sulfoxide in this reaction sequence was further investigated [32]. The authors demonstrated that 1,2,3,5-tetrahydroxybenzene was formed from pyrogallol and dimethyl sulfoxide in crude extract: after a lag phase, formation of phloroglucinol started while the concentration of tetrahydroxybenzene remained constant. This result suggests that pyrogallol conversion to phloroglucinol in $E$. oxidoreducens is a transhydroxylation reaction as well. This is supported further by obvious similarities between the $P$. acidigallici enzyme and that of $E$. oxidoreducens. Both enzymes have a neutral $\mathrm{pH}$ optimum (7.0 and 7.3; [10]), an acid $\mathrm{p} I$ (approx. 4.0, as estimated from the chromatofocusing data [10]), and both are not inhibited by oxygen, EDTA ( $1 \mathrm{mM})$, cyanide $(1 \mathrm{mM})$, and iodoacetate $(1 \mathrm{mM})$, but strongly inhibited by $p$-chloromercuribenzoic acid. For the purified enzyme of $P$. acidigallici, a reliable metal analysis is presented here which identifies transhydroxylase as a MoFeS protein. According to data of a preliminary metal analysis, these elements were also found in the enriched enzyme preparation of $E$. oxidoreducens.

Both enzymes differ with regard to regulation. While in $P$. acidigallici transhydroxylase is expressed constitutively, it is induced in E. oxidoreducens by gallate [32]. This result is understandable since $P$. acidigallici grows only with trihydroxybenzenes [8], while the rumen bacterium is more versatile and uses also crotonate. In any case, inductive regulation of transhydroxylase would be very uneconomic in $P$. acidigallici considering the high fraction of enzyme protein in relation to total protein content.

Further studies on the $P$. acidigallici transhydroxylase in our laboratory will concentrate on the arrangement and functional organization of $\mathrm{Fe}, \mathrm{S}$, and $\mathrm{Mo}$ in the enzyme protein.

\section{Acknowledgements}

We thank Monika Richter for performing inductively coupled plasma mass spectrometry analysis and Petra Merkel for technical assistance with atomic absorption spectrometry analysis. Helpful discussions with Prof. Dr. J. Rétey are greatly appreciated.

\section{References}

[1] Evans, W.C. (1977) Nature, 270, 17-22.

[2] Schink, B., Brune, A. and Schnell, S. (1992) in Microbial Degradation of Natural Products. (Winkelmann, G., ed.), pp. 219-242.

[3] Evans, W.C. and Fuchs, G. (1988) Annu. Rev. Microbiol. 42, 289-317.

[4] Koch, J. and Fuchs, G. (1992) Eur. J. Biochem. 205, 195-202.

[5] Brune, A., Schnell, S. and Schink, B. (1992) Appl. Environ. Microbiol. 58, 1861-1868.

[6] Schnell, S., Brune, A. and Schink, B. (1991) Arch. Microbiol. $155,511-516$.

[7] Krumholz, L.R., Crawford, R.L., Hemling, M.E. and Bryant, M.P. (1987) J. Bacteriol. 169, 1886-1890

[8] Schink, B. and Pfennig, N. (1982) Arch. Microbiol. 133, 195-201. 
[9] Samain, E., Albagnac, G. and Dubourguier, H.C. (1986) Arch. Microbiol. 144, 242-244.

[10] Krumholz, L.R. and Bryant, M.P. (1988) J. Bacteriol. 170, 24722479.

[11] Brune, A. and Schink, B. (1990) J. Bacteriol. 172, 1070-1076.

[12] Bradford, M.M. (1976) Anal. Biochem. 72, 248-254.

[13] Laemmli, U.K. (1970) Nature 227, 680-685.

[14] Heukeshoven, J. and Dernick, R. (1985) Electrophoresis 6, 103-108.

[15] Singer, T.P., Salach, J., Hemmerich, P. and Ehrenberg, A. (1971) in Methods of Enzymology (McCormick, D.B. and Wright, L.D., eds.), Vol. 18 B, pp. 416-427.

[16] Beinert, H. (1983) Anal. Biochem. 131, 373-378.

[17] Jocelyn, P.C. (1972) Biochemistry of the SH-group, Academic Press, London.

[18] Stryer, L. (1988) Biochemistry, Freeman, New York.

[19] Orme-Johnson, W.H., Jacob, G.S., Henzel, M.T. and Averill, B.A. (1977) in Bioinorganic Chemistry II (Raymond, K.N., ed.), pp. 389-401, American Chemical Society, Washington, DC.

[20] Wootton, J.C., Nicolson, R.E., Cock, J.M., Walters, D.E., Burke, J.F., Wendy, A.D. and Bray, R.C. (1991) Biochim. Biophys. Acta 1057, 157-185.

[21] Bray, R.C. (1988) Q. Rev. Biophys. 21, 299-329.
[22] Börner, G., Karrasch, M. and Thauer, R.K. (1991), FEBS Lett. 290, 31-34.

[23] Cramer, S.P. and Stiefel, E.I. (1985) in Molybdenum Enzymes (Spiro, T.G., ed.), pp. 411-442, Wiley-Interscience, New York.

[24] Garner, C.G. and Bristow, S. (1985) in Molybdenum Enzymes (Spiro, T.G., ed.), pp. 343-410, Wiley-Interscience, New York.

[25] Bray, R.C., Turner, N.A., Le Gall, J., Barata., B.A.S. and Moura, J.J.G. (1991) Biochem. J. 280, 817-820.

[26] Moura, J.J.G., Xavier, A.V., Bruschi, M., Le Gall, J., Hall, D.O. and Cammack, R. (1976) Biochem. Biophys. Res. Commun. 72, 782-789.

[27] Barata, B.A.S., Liang, J., Moura, I., Le Gall, J., Moura, J.J.G. and Boi, H.H. (1992) Eur. J. Biochem. 204, 773-778.

[28] Moura, J.J.G., Xavier, A.V., Cammack, R., Hall, D.O., Bruschi, M. and Le Gall, J. (1978) Biochem. J. 173, 419-425.

[29] Stackebrandt, E., Wehmeyer, U. and Schink, B. (1989) Syst. Appl. Microbiol. 11, 257-260.

[30] Johnson, J.L., Rajagopalan, K.V., Mukund, S. and Adams, M.W.W. (1993), J. Biol. Chem. 268, 4848-4852.

[31] Krumholz, L.R. and Bryant, M.P. (1986) Arch. Micobiol. 144, 8-14.

[32] Haddock, J.D. and Ferry, J.G. (1993) J. Bacteriol. 175, 669-673. 